\title{
Changes and Development of Civil and Commercial Law in Social and Economic Development
}

\author{
Hongfei Zhang ${ }^{1, a}$ \\ ${ }^{I}$ Faculty of Law, Nanchang Institute of Technology, Nanchang, China \\ azhanghongfei@nue.edu.cn
}

\begin{abstract}
With the progress and development of the socialist economy in China, at the same time, the legal cause of our country has also made great progress, so that the legal system of our country is further improved and strengthened. The reform of the judicial system has greatly affected the value of the civil and commercial law. In order to adapt to the development and progress of the times and meet the needs of society, the civil and commercial law should make appropriate changes and adjustments. In the paper, the main content is to analyze and study the changes and development of the value system of civil and commercial law in the process of social and economic development focusing on the relevant core contents of civil and commercial law.
\end{abstract}

Keywords: social and economic development, civil and commercial law, change and development

\section{INTRODUCTION}

Civil and commercial law plays an important role in people's daily life. In particular, under the continuous promotion of social economy, the civil and commercial law has been continuously developed and changed with the continuous development and change of social economy and a corresponding change is made. Throughout the process of development and change[1], the civil and commercial law should conform to the development of the times. With the change of social economy, it's to make change. Only in this way can we contribute to its development and eliminate some potential hidden dangers. Under the premise of the constant development and progress of the social economy, the civil law should be further supplemented and explained. At the same time, we can keep up with the pace of the times, conform to the requirements of the development of the times, and make a contribution to the social economy[1].

\section{2. THE CONNOTATION COVERAGE OF CIVIL COMMERCIAL LAW}

AND

The civil and commercial law is the law that can promote and standardize the people's livelihood activities and to guide the development of the people's livelihood activities, and to encourage the people's livelihood activities to be stable, positive, and can establish an equal, civilized and fair market competition environment with the full efforts of a nation. The civil and commercial law is mainly to adjust some of the main body relations in the market economy by giving the market main duty and the right. Private law and rights law are the essence of civil and commercial law, and the law of people's livelihood. The private law and the right method are the essence of the law of the people and the people's livelihood, its core is freedom and equality, it protects the rights of individuals as a basic, and can effectively adjust the relationship between equal subjects[2], life and property, so that the interests of the individual can be maximized, and the individual's creativity and initiative can be fully mobilized. However, with the continuous progress and development of modern society, in order to effectively improve the security in the transaction process, in civil and commercial law, the relevant mandatory provisions of each country are also subject to increased changes as their social development changes. In addition, in this process, the public law component is gradually infiltrated into the civil and commercial law. The main content of the civil and commercial law is the regulation of the main body and the act and the power and responsibility in the course of the people's livelihood. The main purpose of the civil and commercial law is to restrict the various subjects of the transaction behavior under the market economy environment. Its main task is to regulate and adjust the various necessary factors in the process of running the market economy[2].

\section{THE INFLUENCE OF THE DEVELOPMENT OF THE SOCIAL ECONOMY ON THE MINSHENG LAW}

With the progress and wide application of science and technology, changes are taking place in all areas of the present society. With the emergence of this change, the whole society is making continuous progress and development in the direction of informatization, technicalization and science and technology. Although China has a cultural history of 5,000 years, and all generations of each dynasty have a relatively perfect legal system. However, with the progress of science and technology, the law of China is also making this corresponding change with the development of society, which can make the law conform to the requirements of the times, meet the needs of people, really proceed from the reality and play a role in the benefit of mankind. Under the great influence of the development of the socialist economy, the civil and commercial law has also been 


\section{affected}

The influence of value. With the development and change of China's social and economic system, the civil and commercial law has also been affected by its values, and the main reason why its values are affected is that more attention has been paid to the safety and effectiveness of civil and commercial law. In the traditional civil and commercial law, the security system is in a derivative position as the information itself, in a more traditional approach, is not subject to excessive transaction security. Even if the transaction information is obtained by a third party[3], it will not pose a direct threat to the transaction. Therefore, in the more traditional way of trading, because the way of transaction is the clearing of money and goods, goods and money transactions are carried out at the same time, or face-to-face. However, due to the continuous development of information technology and the continuous popularization and application of network technology, civil and commercial law in the development of space has to be constantly expanded and changed. Based on the change of the times, all countries and regions will be affected by the Internet so that there will be some security problems in the transaction that would not have existed before. The market transaction form structure has changed, and the development level of each technology has been unceasingly raised. Therefore, in the process of transaction, people not only pay more attention to the commodity exchange problem, but also the aging and safety issues. People can share information by means of the network and people can get the information they want through a certain software. As a result, the transaction can be done through some corresponding techniques, such as the internet. This kind of transaction can be implemented at any time and place.

The reconstruction of the system of civil and commercial law, in the contemporary China, includes the benefit, the freedom, the equity, the equality and the safety, etc for the content of the civil and commercial law[4]. Security, as the basis for the implementation of civil and commercial law, should be regarded as the core template of the whole system, no matter what system the civil and commercial law is carried out. In the system of safety law, it is not only to ensure its benefit, but also an important issue that can't be ignored. Therefore, the process of making the legislation on the Minsheng law should ensure the unity and coordination of the benefit and the safety[5].

\section{THE CHANGE AND DEVELOPMENT OF THE BASIC PRINCIPLES OF CIVIL AND COMMERCIAL LAW}

The principle of benefit. It is difficult to solve the problem of ensuring the fairness while ensuring the benefit. From the point of view of law, its fairness and justice are the starting point of law making and enforcement. The existence of law is to safeguard social fairness and justice. Therefore, in the whole process of the formulation and modification of the law, the principle of equity and justice should be paid attention to, and the principle of benefit and other aspects should be taken into account. Only the law that has been developed can the development of the requirements of the times be met. The most fundamental purpose of the law is to effectively embody the interests of the ruling class. It can change the interests of the ruling class and make different changes with the change of the ruling class in different historical periods. In the course of this change, the basic principle of the possible law also changes with the development of society. Therefore, in the process of continuous progress and development of China's socialist economy, the formulation of civil and commercial law needs to be fully considered and analyzed in all aspects of its current economy to make an advantageous modification in order to build a better socialism[2].

Safety principles. With the continuous popularization and application of information technology, its network is widely used, which makes people's information and other aspects of the security may be threatened and the definition of security is broader and deeper than before[5]. The principle of safety is the basis of civil and commercial law for all civil and commercial activities. At the same time, in the whole process of the legislation of civil law, the safety principle needs to be fully embodied. In the process of the legal development of the civil and commercial law, it is necessary to fully reflect the practical requirements of the civil and commercial law on the issue of security.

The principle of equality and neutrality. In the present moment of China's socialist economic development, the principle of equality and neutrality of the civil and commercial law refers to the direct intervention among different and more subjects. It ensures that people's livelihood activities in the process, fully reflected in line with their conditions and needs, namely, in the course of the activity, it interferes with a number of different trading platforms, ensuring that the process of the transaction is fair, and ensuring that the transaction does not have any bias problems[1].

\section{THE DEVELOPMENT OF CIVIL AND COMMERCIAL LAW}

The prerequisite of the establishment of the civil and commercial law is to have a perfect system. However, under the continuous progress of society, the connotation of civil and commercial law is also constantly enriched and the legal system has been further improved. In the development of civil and commercial law, it has a direct bearing on the results of the civil and commercial activities.

With the continuous progress and development of the market economy system, China has initially established many civil and commercial legal systems, such as intellectual property system, market subject system, social security system and contract legal system. However, from the aspects of the current situation of legislation, it is found that there is still a shortage of supply in China's civil and commercial law. From the aspects of quality, quantity and systematization, it is still difficult for China's theory and practice of civil and commercial law to coordinate with the socialist market economy and difficult to develop continuously. Although there are a lot of legislation on civil and commercial law, it is lack of systematicness, which has led to repeated phenomena in the content of the 
[5] Yang Tiantian. On the Change and Development of the Civil and Commercial Law in the Development of Social and Economic Development [J].The Legal World of Staff and Workers, 2018, (18): 16.

\section{CONCLUSION}

as the basic system of the socialist market economy system, the civil and commercial law plays an important role in the economic development. The civil and commercial law can be more perfect, which can make the competitive environment of market economy more fair, and the operation of the market more stable. With the progress and development of China, civil and commercial law has also been further developed and improved and the civil and commercial law is also more broad in the scope of the market[5].

\section{REFERENCES}

[1] Wu Xingqu. Changes and Development of Civil and Commercial Law in Social and Economic Development [J]. Legal System Expo, 2018, (36): 242.

[2] Xu Weisen. Study on the Change and Development of the Civil Law in the Process of the Social and Economic Development; [J]. Consumer Guide, 2018, (32): 196.

[3] Zhang Tao. Discuss the Change and Development of Civil and Commercial Law in Social and Economic Development. [J].The Legal World of Staff and Workers, 2018, (24): 224.

[4] Hao Xue. The Change and Development of the Civil and Commercial Law in the Development of the Social and Economic Development [J].The Legal World of Staff and Workers, 2018,(16):140. 